\title{
Understanding Multiculturalism in a Family on Whatsapp Group in the Disruption Era
}

\section{Memahami Multikulturalisme dalam Keluarga pada Whatsapp Group di Era Disrupsi}

\author{
Sri Seti Indriani ${ }^{1}$, Ditha Prasanti ${ }^{1}$ \\ ${ }^{1}$ Faculty of Communication Sciences, Universitas Padjadjaran, Jl. Raya Bandung \\ Sumedang KM 21, Jatinangor 45363, Indonesia \\ *Corresponding author, e-mail: seti@unpad.ac.id
}

\begin{abstract}
The SW6 family spread in several locations creates multiculturalism on WhatsApp social media groups. This study tries to describe the meaning of multiculturalism family on the WhatsApp group for the family members. This study is qualitative type using virtual ethnographic approach to describe the reality. The results of the study reveal that the experience of communication experienced is referred to as an archipelago insight experience. Cultural intelligence is assessed from the personal activeness of family members and information shared. When talking about something outside of its cultural values, there are some of the family members who choose to be silent, there are some who choose to ask questions to understand, but there are some who directly express their feelings. Communication culture can also be seen from the personal activeness of each members, there is a silent reader, some respond when needed, some are positioned as followers and some are dominant.
\end{abstract}

Keywords: Multiculturalism, Social Media, Family Communication, Cultural Intelligence.

\begin{abstract}
Abstrak
Keluarga SW6 yang tersebar dalam beberapa lokasi menciptakan multikulturalisme dalam grup sosial media WhatsApp. Penelitian ini mencoba mendeskripsikan bagaimana makna keluarga multikulturalisme dalam WhatsApp Group bagi anggota keluarga tersebut. Studi ini berjenis kualitatif dengan menggunakan pendekatan etnografi virtual untuk mengambarkan realitas. Hasil penelitian mengungkapkan bahwa pengalaman komunikasi yang dialami disebut sebagai pengalaman wawasan nusantara. Kecerdasan budaya dinilai dari keaktifan personal anggota keluarga dan informasi yang dibagikan. Ketika membicarakan sesuatu di luar nilai-nilai budayanya, ada sebagian yang memilih untuk diam, ada beberapa yang memilih untuk bertanya agar memahami, namun ada pula yang langsung mengungkapkan perasaannya. Budaya komunikasi terlihat juga dari keaktifan personal masing-masing anggota, ada yang silent reader, ada yang menanggapi ketika diperlukan, ada yang berposisi sebagai pengikut dan ada pula yang berperan dominan.
\end{abstract}

Kata Kunci: Multikulturalisme, Media Sosial, Komunikasi Keluarga, Kecerdasan Budaya.

\section{Introduction}

This study is based on the study results of the previous studies that have been carried out previously by the research team. Several of the previous studies, among others: first, the study conducted by Rachmaniar \& Anisa (2017) with the title 'Loyalitas Peserta Grup WhatsApp (The Loyality of WhatsApp Group Members)' using descriptive method. The difference with this study is on the aspects of the method and also on the scope of the discussion which is more focused on the new culture resulted from the 
cultural diversity that lies behind the members of the SW6 Group (Soenjoto Wiroatmodjo Sixth Generation Group).

Second, the research conducted by Bhakti, Paradisa, Alkaf, \& Irwansyah (2018) with the title 'Pengaruh Media Sosial terhadap Pengalaman Multikultural dan Kecerdasan Budaya (The Influence of Social Media on Multicultural Experience and Cultural Intelligence)'. Their research suggests the link between the use of social media and multicultural experiences, and one's cultural intelligence. The study uses quantitative method using online survey. The difference with the researchers' study is the method used is qualitative method with virtual ethnographic method that allows the depiction of the results of research descriptions and interpretations of the informants more thoroughly and deeply.

Third, the research conducted by Khalid (2017) with the title 'Impact of Internet on Social Connections in Family System', focused on family relations like this study, but Khalid used quantitative method, while we used qualitative method. For the other previous studies, many raised cultural communication in social media but did not focus on the new culture that emerged as the result of communication experience, cultural intelligence and the meaning of multiculturalism on the WhatsApp Group. Therefore, for the renewal of this study when compared to the previous studies, it is on the SW6 WhatsApp Group members whose members are scattered in several places throughout Indonesia. This allows for different interpretations in communication because of the cultural differences of each member. This has led to multiculturalism in a social media group platform. This study is important because these conditions are increasingly relevant where people have made social media their primary means of daily communication.

Social media itself makes it easy for people to communicate over time and place. One social media like WhatsApp makes it easy for each members to form a group or community to interact continuously, either about work, strengthen friendship or strengthen family gathering. Social media also allows various cultures to be collected in the community platform.

The role of the media in the family communication is increasing, seeing changes in time that force people to change the way they communicate. It is not weird in this disruption era that almost all family members join in a family communication group facilitated by social media. Social media is an online media that users can easily participate, share and create the content (Satyadewi, Hafiar, \& Nugraha, 2017). Based on a study, there were $25 \%$ informants from 400 informants who were respondents becoming the subjects of their research strongly agreed that they used the internet to intensify the relations with their families (Khalid, 2017).

The disruption era is defined as innovation that helps create new markets and disrupts or damages the existing markets (Hendrawan, 2019). It replaces the 'old market' of industry and technology to produce more efficient and comprehensive novelty. It is called destructive and creative. From this explanation, it can be assumed that the disruption era is an era of change that has one positive and creative side but also on the other side is negative because it has damaged or 'forgotten' the old thing. The research conducted focuses on a family communication facilitated by the Whatsapp group application. This family communication is originally face-to-face communication which is rare because the differences of location becomes communication through social media. 
In this study, communication is easy because it passes the time and place through social media, but also makes people become less appreciative of the existing communication because they have forgotten some rules of communication ethics. The internet is the latest mode of communication and socialization that reduces face to face or telephone contact. The internet expands the gap among individuals by isolating them and reducing the time spent to participate in social activities (Khalid, 2017).

Social Media is very popular in this era of disruption because it has replaced the 'old' way people communicate to new creative way of communication. The social media seems now to have become a popular component in everyday life. Social media provides a context that makes it easy for people from all over the world to communicate, to exchange messages, to share knowledge and to interact regardless of the distance boundaries among them (Sawyer \& Chen, 2012). In accordance with the quote of Chen \& Zhang, (2010) "The compression of time and space, due to convergence of the new media and globalization, has shrunk the world into a much smaller interactive field" (Taiwo, 2010). The quote confirms how the changes made by the new media make the world a smaller field of interaction. Social media changes social relationship because it facilitates people to keep connecting and sharing information (Khalid, 2017).

As discussed earlier, one of the popular social media in Indonesia is Whatsapp. Indonesia is in the top five regions with the highest growth according to Brian Acton as quoted by Rachmaniar \& Anisa (2017). (Yusuf, 2016) stated that there were already 1 billion monthly active users as of February 2016 with 42 billion messages and 250 million videos sent through the service each day (Anisa, 2018).

WhatsApp application has become one of the human needs in daily life. Starting from the needs in interacting personally to the needs that involve one's job. This social networking application makes it easy for every people to communicate and to interact as well as facilitates everyone's activities. Based on the results of the preliminary interview, DAR (an informant) who worked in the contractor field said that communication with Whatssapp was very efficient and very effective in facilitating his field of work. His field of work as a contractor is made easier by the Whatsapp application that can send pictures or videos to each other.

IN (another informant) said that Whatsapp provides an opportunity to be able to keep communicating with his extended family in several places in Indonesia, "we initially only meet and interact once a year on Eid ... now with the family group on whatssapp we are able to know about the news from other families." MA who was also an informant and was in the Whatsapp family group like IN, said that with the diversity of cultural backgrounds in his family because of the differences in their place of residence enriched the interactions that occurred in the Whatsapp group. MA emphasized that the multiculturalism that exists in the Whatsapp family group provides a broader archipelago insight.

Multiculturalism is an interesting social phenomenon and is often regarded as a challenge in the study of communication. The existence of new media provides greater opportunities in building communication and also building relationships among people in the global dimension. All of these allow the development of communication horizontally which creates creative social groups and social communities (Piechota, 2015). The explanation assumes that with the presence of social media, it can provide a high enough opportunity to gather various cultures in one forum, namely the social media platform. 
Multiculturalism incorporated in a social media demands cultural intelligence among the members who are fostered in a community forum in the social media group. 'People from different cultures adhere to different social norms, values, and traditions, resulting in disparate ideas and perspectives on a given problem' (Chua, 2018). The quote emphasizes that people who come from different cultural backgrounds following different social norms, values and traditions certainly produce different ideas and perspectives if there is a problem.

Meanwhile, the family members studied are members of the SW6 Whatssapp Group located in different environments. Some of them live in East Java, who are consciously influenced by the procedures and behavior as well as mindset of East Java culture, also those who are in West Java mainland, more often behave like Sundanese people. With the many differences in terms of ideas and perspectives, it is necessary to have high enough cultural intelligence so that the communication that occurs in the social media group runs effectively. Cultural intelligence is an awareness of culture. Cultural awareness is a person's attitude to appreciate, to know and to understand the existence of the differences which exist in that culture.

This SW6 Family Whatsapp Group study does not only look at communication but also communication among cultures, culture and communication can not be separated because however culture is also the basic foundation of communication (Sanadi, 2014). The disruption era is in the spotlight because of its unavoidable nature. The focus of this study is to see how the communication experience occurred among family members in the SW6 Family Whatsapp Group, the meaning of multiculturalism in SW6 Family formed in Whatsapp Group, and how cultural intelligence in the SW6 Family Whatsapp Group is.

\section{Methodology}

This study was conducted using qualitative method with virtual ethnographic approach. Qualitative research method is naturalistic research method because the assessment is carried out in natural conditions (Sugiyono, 2010). The virtual ethnographic methodology approach has been expanded and reformed through new proposals such as digital ethnography, ethnography on/from/via the Internet, bound ethnography, network ethnography, cyberethnography, etcetera (Domínguez et al., 2007).

Ethnography itself is qualitative research design in which a researcher describes and interprets patterns that are exchanged and learned from cultural groups about values, habits, beliefs, and language (Nasrullah, 2017). Virtual ethnography is simply defined as an ethnographic method used to uncover reality, both visible and not, from computer-mediated communication among viral community entities on the internet (Nasrullah, 2017). The virtual world itself can be described as a genre of online communities that forms a computer-based simulation environment. The virtual world is intended for the users to inhabit these virtual places and to interact with each other (Firat \& Yurdakul, 2011).

The data collection technique used is in-depth interviews both online and off-line. This was done to clarify and to confirm the interviews conducted online. The pattern of online and offline interviews is the pattern that must be done by virtual ethnographic researchers, to prevent information bias and the uncertainty of data validation (Arif, 2012). Ethnographic research basically includes observations and interviews conducted with individuals and other related people to describe or to explain their daily 
experiences. In this type of research, the main tools consisted of in-depth interviews and constant observations used in all ethnographic studies (Firat \& Yurdakul, 2011). The researchers conducted face-to-face interviews with several informants who were members of the SW6 Family WhatsApp group and observed the group interactions online. For observations they are participant online, observe directly the development of the community or group, see the dynamics or issues, themes discussed and at the same time examine verbal and non verbal used in the conversation.

\section{Results and Discussion}

Social networking or social media sites initially emerged based on an idea or thought to gather people from all parts of the world (Watie, 2011). As time went on, social media became the main tool for people to communicate, especially for those who were far apart. This social media then became the right place for the SW6 Family to communicate.

The SW6 family is a large family whose family members live far from each other. Members are spread in various parts of Indonesia, some even abroad. Their residences are located in Bandung, Tasik, Bogor, Yogyakarta, Surabaya, Jember, Palembang, Medan, and Solo. There are also those who live in Australia and Germany. Before the digital era which becomes people lifestyle in this era of disruption, the communication occurred among these large families was more in correspondence or occasional telephone calls, and Eid day was a day that was intended to come and to gather in one of the family members. An informant named IN said that he was always reminded of the days of gathering on Eid holidays in 1990-1998. He felt that the gathering agenda was always important so that all family members must attend. Even the family members who lived in Australia and Germany took the time to return to Indonesia.

When digital times began to penetrate most of human life, social media began to provide convenience in communicating. The internet creates more closeness with their families and also their friends (Khalid, 2017). One of the SW6 members then created a Whatsapp family group in May 2015 consisting of a majority of 23 members of SW6. The four-year group Whatsapp family is running. For four years, an informant admitted that it was not easy to keep being in the group. Many communication experiences that were experienced by these families, both in the form of harmony, to the experience of conflict that has resulted in some group members leaving the group. Conflict that occured was the result of the existence of a communication that was less effective. Differences in cultural background are one reason why communication is less effective. Different cultures are different habits, different habits are different perceptions. Different perceptions among cultures will find misunderstandings in communication if we are not aware of the various communication barriers that arise (Simbolon, 2012).

Until now, only 23 members are still in the SW6 Whatsapp group. The following is the table 1, the information about the Whatsapp member:

Table 1. The Information on Family Members in the SW6 WhatsApp Family Group

\begin{tabular}{cccc}
\hline No & Initial & Age & Location \\
\hline 1 & IN & 38 & Bandung \\
2 & MO & 48 & Palembang \\
3 & RS & 37 & Bandung \\
4 & HD & 50 s & Jember \\
5 & MAK & 69 & Soreang
\end{tabular}




\begin{tabular}{cccc}
6 & BI & $60 \mathrm{~s}$ & Bandung \\
7 & BR & $60 \mathrm{~s}$ & Cilegon \\
8 & MT & $60 \mathrm{~s}$ & Cilegon \\
9 & MC & $40 \mathrm{~s}$ & Surabaya \\
10 & MIR & $40 \mathrm{~s}$ & Bandung \\
11 & MN & 36 & Surabaya \\
12 & ESP & 68 & Soreang \\
13 & WT & 78 & Jerman/Bogor \\
14 & WOZ & 70 & Australia \\
15 & MAN & $40 \mathrm{~s}$ & Surabaya/Bali \\
16 & DIN & 38 & Bandung \\
17 & PS & $50 \mathrm{~s}$ & Tasik \\
18 & BAH & $60 \mathrm{~s}$ & Yogyakarta \\
19 & LE & 33 & Jakarta \\
20 & MA & $50 \mathrm{~s}$ & Tasik \\
21 & MS & $40 \mathrm{~s}$ & Surabaya \\
22 & MR & $50 \mathrm{~s}$ & Jember \\
23 & YU & $50 \mathrm{~s}$ & Solo \\
\hline
\end{tabular}

The cultural differences in the SW6 family consist of differences that arise because of the different cultural backgrounds produced from their place of residence. Members who live in Surabaya, Solo, Jember and Yogyakarta use Javanese language more often, while those who live in West Java prefer using Indonesian with a little Sundanese language. Members of the family who live in Palembang have distinctive communication style in the style of North Sumatra people. Apart from these cultural differences, there are also religious differences, most of them are Moslems but some are Hindus and some even though they are Moslems they live in the Christian neighbourhood. Another difference is the difference in age. This happens because the family members consist of those who have the status of grandmothers or grandparents to those who are children of aunts who also have their own families.

These differences create a distinctive culture within the group. This can be seen from the way they communicate. Culture and communication can not be separated because however culture is also the basic foundation of communication (Sanadi, 2014). The new culture creates a new culture of communication on WhatsApp social media. As explained by RS at the time of the interview, there were those who were dominant, there were those who became silent readers, some who commented on safe times. Friction was sometimes unavoidable when one member said something then got criticism from other members. According to IN, those who are silent readers are those who have quite different ages and are somewhat younger. While those who are dominant are those who are considered senior. Javanese language is indeed the dominant language even though it is not the perfect Javanese language, only the language whose form emphasizes a sentence. According to RS, who does not understand Javanese language, the use of the Javanese language is due to the fact that most senior family members have lived long in the mainland of East Java, so that Javanese language becomes their mother tongue.

The experience and the meaning of multiculturalism in the SW6 Whatsapp Group is different for each member involved in it. An event that contains elements of communication will be a separate communication experience for individuals, and communication experience that is considered important will be the most memorable experience and has special impact on the individual (Hafiar, 2012) When RS was asked 
about his communication experience in the group, he answered with a sigh. He considered it was not easy because what he remembered was communication experiences that made him have to be careful when commented in groups. He does not want his comments to offend others or discredit others. MA acknowledges that when communicating in groups we must have high enough tolerance, not directly criticize a comment. Meanwhile, IN makes it habit to comment when it is needed and does not involve feeling too much.

RS told one of his experiences when one member who is Moslem, WOZ shared a link which essentially contained how non-Moslems would go to hell. The link became problem when one family member who was Hindu (MS) said that the link was 'hoax' and was not reasonable. This incident caused a long period of polemic and tension because in addition to having different perceptions, WOZ thought that MS was not polite because MS was much younger than him. Even though the friction was tense by itself, it faded with the attitude of MS who was Hindu apologized in the Whatsapp group.

Another experience was when RS reported that his child was sick and that he was being treated at the hospital. RS did not get the proper support, instead he got criticism with how he educated his children. This experience made him reluctant to tell others when his son was sick. He prefered being quiet and not telling anyone.

Based on the communication experience occurred in this Whatsapp group for approximately four years, the culture in the group was formed. The culture is formed so that each of them can adapt and accept each other despite having different cultural backgrounds. Intercultural adaptation involves process of understanding through interaction to increase the level of conformity so that the demands of the new cultural environment can be met (Chung et al., 2015). According to IN, the culture is more careful when commenting. Information or news that becomes the topic is objective and safe so that it will not offend anyone, does not confuse something related to the issue of SARA. The Islamic religious link is more on information that is neutral in tone.

MA feels that the existence of the Whatsapp family group is a good thing, seeing the various cultures in one family starting from the tribe, religion and the place they live. MA stated that his communication experience was the archipelago insight. This is emphasized because it gets a wide range of insights or information because information comes from different places. MA stated that his family was Pancasila family. Although there were some frictions, but it still could be overcome. Having high tolerance attitude is one of the way in order to make the communication in the Whatsapp group runs effectively. Yeke \& Semerciöz (2016) explained that cultural intelligence influenced one's level of tolerance (Bhakti et al., 2018). MA mentioned several concerns seeing some members who were less dominant in the group. They were minorities. He mentioned there were two members with different religious backgrounds. Even though MA felt sad about their choice to choose different religion, it was revealed.

IN agreed that the SW6 Family has become stronger since the presence of this Whatsapp group. Like other informants, he realizes the benefits such as getting accurate information from certain locations. He can re-check information whether the information is a hoax or not. He also strongly agrees if his communication experience in the group is referred to as an archipelago insight experience. This is because he can know the description of information in several locations in Indonesia and also in Australia or Germany. IN emphasizes that he can also learn Javanese language. IN, who lives in Bandung and is exposed to the Sundanese language environment, with this 
Whatsapp group he is also exposed to Javanese language that finally gives more knowledge about the Javanese language itself. IN, which acknowledges that there is considerable tolerance for differences in the SW6 family, also gives the meaning of his family as Pancasila family because of the varying perspectives of each members. Differences that exist are not problem and even more ruled out. This is also said by MA, who says the differences do not become a polemic.

'Multiculturalism is also considered to be perceived on more levels. From the traditional systematic, understanding of multiculturalism as a structure created by people of different nationalities, cultures, ethnicity and religion that inhabit a given territory to perceiving family as a new scope of research in this respect. In families there are no borders of homogeneity of nationalities, cultures or religions of partners' (Piechota, 2015).

The quotation above emphasizes how multiculturalism is felt in various levels of life from the traditional to the structure made by people of various nationalities, cultures, ethnicities and religions who inhabit a certain area to view family as a new scope of research in this matter. In a family, there is no limit to the homogeneity of nationality, culture or religion in partners. The SW6 Family is a clear example of how a family does not have the boundaries of homogeneity.

The language used is commonly dominated by Javanese language, this is due to most of the group members have ever lived in Malang that becomes part of East Java for a long time. RA said that they often used Javanese language because it used to be their 'childhood' language, the language used when they lived in Java, either in Jember, Surabaya, Sidoarjo, or Malang. The other members who do not understand Javanese language keep silent and do not respond the conversations. However, sometimes there is a member who translates the Javanese language into Sundanese or Indonesian languages. Figure 1 below is one of the conversations where one of the members shares a funny information that is the combination of Javanese and Sundanese languages.

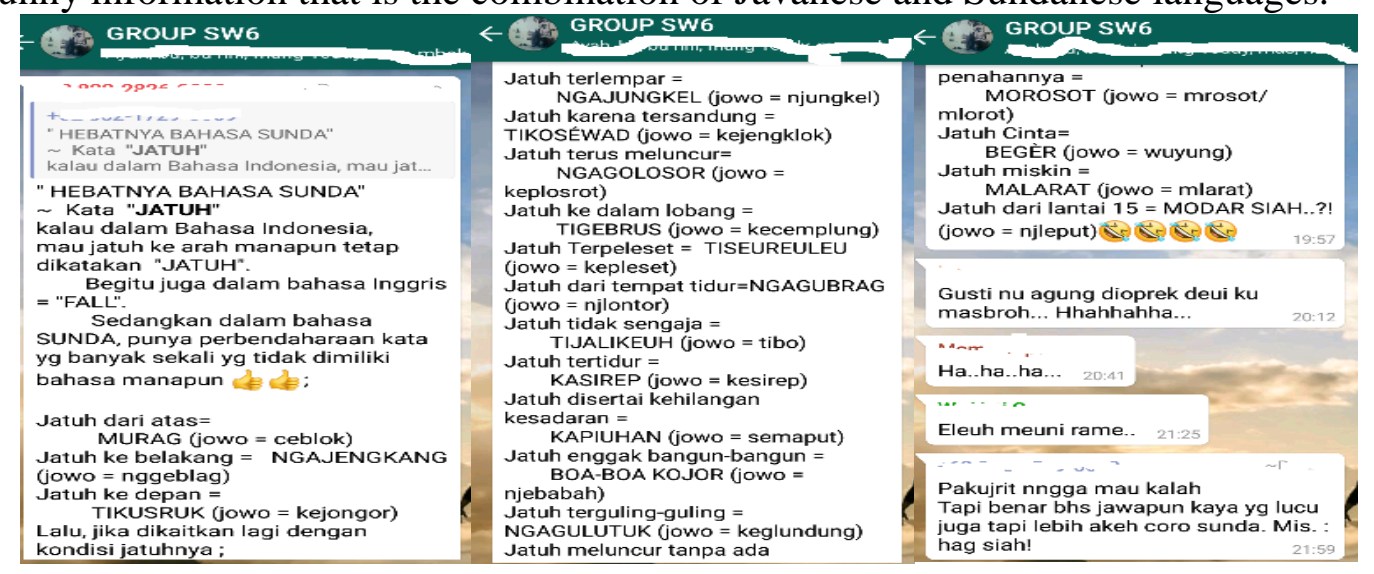

Figure 1. Conversations that show the difference between Javanese and Sundanese Languages (source: SW6 WA Group)

The conversation above shows how they are interested in information related to language differences. Conversations like this become one of their entertainment because they see the situation of those who have different backgrounds. So the experience of communication for the family is also informative and provides new knowledge for its members.

RS, who considers himself as one of the most active members in the SW6 group, said that the group existed at an interesting time and some were not. One of the 
advantages he felt was that he was informed about what was happening in several locations, getting actual and accurate information about one of the locations. This was the same as what MA said, as the archipelago insights. The example presented by RS was when the large families got the latest information about what was happening in Australia, or families in Australia got the latest information from those who lived in Jember or Yogyakarta. Another advantage presented by RS was that he could directly ask for information that was obtained outside the SW6 group so that he could ask whether the news or information was a hoax or not.

Regarding the Javanese language that is often used by the SW6 group, RS who can not speak Javanese language because he was born and grew up in Jakarta say that it does not bother him, even he often asks the meaning of language that he does not understand. So he feels that the Javanese language enriches his vocabulary and learning. Social media provides opportunities and challenges in information acquisition, cultural intelligence and creativity (Bhakti et al., 2018). The difference in language contained in the Whatsapp group does not become a big problem in communicating and interacting among the members, but the difference sometimes results in less effective communication. IN, who does not understand Javanese language, says that it does not matter too much because he has already been familiar and he has understood it.

IN, MA, RA, ES and EP who are the informants in this study as well as the members of SW6 Whatsapp Group are the people who get a lot of cultural differences both from domestic and abroad. This implies that they understand cultural differences and have quite high cultural intelligence. Ang, Dyne, \& Rockstuhl (2015) say that cultural intelligence reflects a common set of abilities that facilitate someone in a different culture and in a multicultural environment (Latif, 2017). Those who have high cultural intelligence are also aware of cultural differences. If they are more aware of cultural differences they will be more tolerant and more able to interact well with those who have different cultures (Bhakti et al., 2018).

Most of the SW6 members prefer to be silent readers. Most of the others are dominated by members who have high cultural intelligence because of their high tolerance attitude. They are not easily confused when there are differences and choose to see it from the positive perspective.

\section{Conclusion}

This research reveals that the communication experience that was experienced by SW6 Family group members is referred to as an archipelago insight experience. This is due to cultural differences and the location of each family members. Most of the informants said that the experience was quite interesting and sometimes ordinary. An interesting experience was when they got new knowledge and the useful information. They can re-check the information that is spread in the real world, whether the information is correct or not.

Communication experience also shapes the culture in the group. The information and subject matter contained in the Whatsapp group is neutral, not nuanced by SARA and the information about a religion is neutral, it does not discredit other religions or boasts another religion. The meaning of family which is formed in this Whatsapp group is the Pancasila family.

Cultural intelligence is judged by the activeness of the family members personally and the information shared. When talking about something outside of their cultural values there are some of them who choose to be silent, there are some who choose to 
ask questions to understand, but there are also some who directly express their feelings when an information is not in accordance with the values contained. Communication culture is also seen from the personal activeness of each members, there are silent readers, some respond when needed, there are followers and some are dominant.

The researchers suggested that the cultural intelligence of each human being should be improved through various trainings, bearing in mind that life is now more or less like a global village that requires people to understand others with various cultural differences. It is recommended that further researches focus on the new cultures such as one that appear in virtual world that can not be equated with non-virtual world. The development of virtual ethnographic studies should be more enriched as an effort to more understand of the world in the digital era nowadays.

\section{Acknowledgments}

The researchers would like to thank to the parties who have contributed in completing this study. Big thanks goes to the SW6 Family WhatsApp Group members who are pleased and glad to be the subjects of this study.

\section{References}

Ang, S., Dyne, L. V., \& Rockstuhl, T. (2015). Cultural intelligence: Origins, conceptualization, evolution, and methodological diversity. In M. J. Gelfand, C.Y. Chiu, \& Y.-Y. Hong (Eds.), Handbook of Advances in Culture and Psychology Volume 5 (pp. 273-324). New York: Oxford University Press.

Anisa, R. (2018). Studi Deskriptif Tentang Loyalitas Peserta Grup Whatsapp. Sosioglobal: Jurnal Pemikiran Dan Penelitian Sosiologi, 2(1), 32-39.

Arif, M. C. (2012). ETNOGRAFI VIRTUAL, Sebuah Tawaran Metodologi Kajian Media Berbasis Virtual. Jurnal Ilmu Komunikasi, 2(2), 165-179.

Bhakti, A. H., Paradisa, I., Alkaf, I., \& Irwansyah. (2018). Pengaruh Media Sosial Terhadap Pengalaman Multikultural dan Kecerdasan Budaya. Jurnal MetaKom, 2, $1-21$.

Chen, G.-M., \& Zhang, K. (2010). New media and cultural identity in the global society. In R. Taiwo (Ed.), Handbook of Research on Discourse Behavior and Digital Communication: Language Structures and Social Interaction. New York: Information Science Reference.

Chua, R. Y. J. (2018). Innovating at Cultural Crossroads: How Multicultural Social Networks Promote Idea Flow and Creativity. Journal of Management, 44(3), 1119-1146. https://doi.org/https://doi.org/10.1177/0149206315601183

Chung, J. E., Conlin, L., Bissell, K., Fardouly, J., Vartanian, L. R., Farhangi, A. A., \& Simmons, N. (2015). The Impact of New Social Media on Intercultural Adaptation. Body Image, 29(3), 1-30. https://doi.org/https://doi.org/10.1080/10410236.2012.741668

Domínguez, D., Beaulieu, A., Estatella, A., Gomez, E. G., Schnettler, B., \& Read, R. (2007). Virtual Etnography. Forum: Qualitative Social Research for Schung, 8(3). Retrieved from http://nbn-resolving.de/urn:nbn:de:0114-fqs0703E19

Firat, M., \& Yurdakul, I. K. (2011). Virtual Ethnography Research on Second Life Virtual Communities. Turkish Online Journal of Distance Education, 12(3), 108117.

Hafiar, H. (2012). Problematika Atlet Penyandang Cacat, Studi Komunikasi Mengenai Kompleksitas Komunikasi Atlet Penyandang Cacat. Bandung: UNPAD Press. 
Hendrawan, A. (2019). Generasi Z Vis-a-Vis Era Disrupsi. In 2019. Retrieved from https://www.academia.edu/36750474/Generasi_Z_Vis-a-Vis_Era_Disrupsi

Khalid, A. (2017). Impact of Internet on Social Connections in Family System: A Survey Study of Residents in Lahore. Arts and Social Sciences Journal, 8(3), 1-6. https://doi.org/10.4172/2151-6200.1000270

Latif, S. (2017). Kecerdasan Budaya Mahasiswa calon Konselor. Jomsign: Journal of Multicultural Studies in Guidance and Counseling, 1(1), 139-148.

Nasrullah, R. (2017). Etnografi Virtual, Riset Komunikasi, Budaya, dan Sosioteknologi di InternetNo Title. Bandung: Simbiosa Rekatama Media.

Piechota, G. (2015). The Role of Social Media in Creating Intercultural Dialogue and Overcoming Prejudice - a Comparative Analysis of Pilot Survey Results. KOME, 2(2). https://doi.org/https://doi.org/10.17646/kome.2014.24

Rachmaniar, \& Anisa, R. (2017). Studi Deskriptif Tentang Loyalitas Peserta Grup WhatsApp. Sosiogobal: Jurnal Pemikiran Dan Penelitian Sosiologi, 2(1), 32-39.

Satyadewi, A. J., Hafiar, H., \& Nugraha, A. R. (2017). Pemilihan Akun Media Sosial INSTAGRAM oleh HOLIDAY INN Bandung. Jurnal The Messenger, 9(2), 153162. Retrieved from https://doi.org/10.26623/themessenger.v9i2.459

Sawyer, R., \& Chen, G. M. (2012). The Impact of Social Media on Intercultural Adaptation. Intercultural Communication Studies, 21(2), 151-169. Retrieved from http://digitalcommons.uri.edu/com_facpubs

Simbolon, D. (2012). Memahami Komunikasi Beda Budaya Antara Suku Batak Toba dengan Suku Jawa di Kota Semarang. Jurnal The Messenger, 4(2), 43-49. Retrieved from https://doi.org/10.26623/themessenger.v4i2.159

Sugiyono, P. (2010). Metode penelitian pendidikan:(pendekatan kuantitatif, kualitatif dan $R \& D)$. Bandung: CV Alpabeta.

Taiwo, R. (2010). Handbook of Research on Discourse Behavior and Digital Communication: Language Structures and Social Interaction. New York: Information Science Reference.

Watie, E. D. S. (2011). Komunikasi dan Media Sosial. Jurnal The Messenger, 3(2), 6975. Retrieved from http://dx.doi.org/10.26623/themessenger.v3i2.270

Yeke, S., \& Semerciöz, F. (2016). Relationships between personality traits, cultural intelligence and intercultural communication competence. Procedia - Social and Behavioral Sciences, 235, $313-319$.

Yusuf, O. (2016, April 13). Angka Fantastis Facebook Messenger dan WhatsAp. 13 April 2016. Retrieved from https://tekno.kompas.com/read/2016/04/13/13160107/Angka.Fantastis.Facebook. Messenger.dan.WhatsApp. 